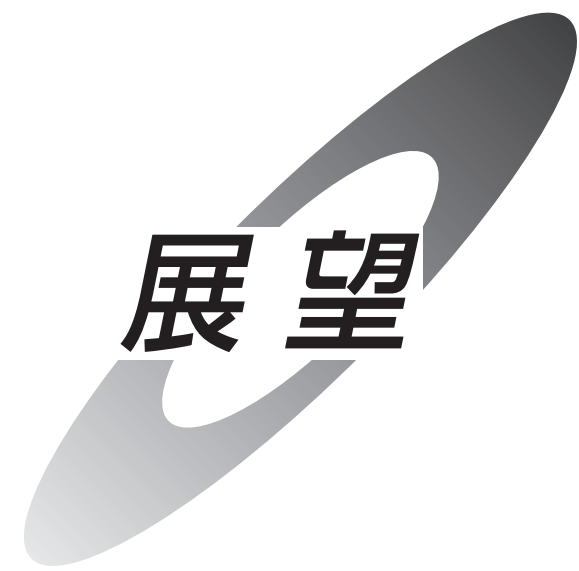

\title{
ポスト万博と 想定内・想定外
}

“自然の䟾智”をメイン・テーマとした愛知万博（2005日本国際博覧会，愛・地球博）が成功裏に終了して, 既に半年以 上が経過した．今回の万博では電気化学関連の様々な技術開発とその成果が，展示は言うに及ばず，実証試験を兼ねたりサ イクル\&エネルギー供給源として裏方でも活躍し，それらを見学するバックヤード・ッアーも大盛況であった．NEDOによ る「新エネルギー等地域集中実証研究プロジェクト」では,「固体酸化物形 (SOFC)」,「溶融炭酸塩形 (MCFC)」,「リン酸 形 $(\mathrm{PAFC}) 」$ のタイプの燃料電池発電に太陽光発電, 電力貯蔵システムを組み合わせ,「マイクログリッド」と呼ばれる小 規模の電力網を構築していた。電気事業連合会, 日本ガス協会や個別企業などの各パビリオンでも, 燃料電池や太陽電池な どを組み合わせて，パビリオンでの消費エネルギーの補助としていたし，燃料電池＋二次電池によるハイブリッド $\mathrm{EV}$ バスが $2 つ の$ 会場間の輸送に活躍していた, 等々. しかしながら万博という, 予算を立てた想定内での実証試験だけでは, 実社会 でも通用するかはまだ灰色の部分があり, さらに䍊の集約が必要である.

万博の開催前から、ポスト万博が課題となっていたが, 万博以後でも幸い, 東海地区はトヨ夕を中心とする自動車関連産 業が活発さを維持しており，「祭りの後の静けさ」を味あわなくて済みそうである.

ところで, 燃料電池といえば, 約 40 年前, 小生が卒業研究で大学の研究室に入ったときに, 既に研究室では先生方や諸先 輩が，基礎研究に取り組まれて扔られた。小生の卒業研究テーマは燃料電池とは無関係であったが，大学に奉職後すぐに， 出身大学の先輩で恩師でもある故伊藤 要先生のもとで, 燃料電池の逆反応である, 二酸化炭素の電気化学的還元に取り組 むこととなった。 それから，10数年後，二酸化炭素による地球温暖化が問題となり，一躍脚光を浴びることとなった。 そし て, 1991年 12 月に, 伊藤 要先生を大会長とし, 世界初となる「化学的二酸化炭素固定国際会議」を名古屋国際会議場で開 催することになり, 小生も事務局担当として, 押手伝いをした。 その時, 現スイス・ローザンヌ大学の M. Grätzel先生が, 当 初の “Catalytic and photocatalytic fixation of carbon dioxide” から, 直前にNatureで発表された「色素増感太陽電池」の講 演に急遽切り替えられたのは，いまでも記憶に残っている。二酸化炭素固定国際会議を企画したときには思ってもいなかっ た，想定外の事柄であった，以来，色素増感太陽電池，いわゆる「グレッェル・セル」の 研究の隆盛さは, 皆様ご存知のと扔りである.

その 5 年前アレックス・ミューラーとジョージ・ベドノルッら発見に端を発する一連の ペロブスカイト型酸化物による高温超伝導体フィーバー, また, 1989 年のいわゆる「常温 核融合」フィーバーなど, 多くの電気化学者を巻き込んだ騒動は, 想定外の事態に対応で きる基礎的な技術力なしには, 起こりえなかったものであり, 別の意味では想定内の事態 とも言える.

と書いているうちに，想定外の事態となった。「想定内・想定外」で昨年の流行語大賞の 一つの発信元となった堀江貴文 (容疑者) 率いるライブドアの家宅捜索と, 堀江貴文（容 疑者）ら数人の逮捕である. 一時期の M\&A ブームに乗って時代の龍児とはやし立てられた 感はあるが, この一連の逮捕劇は, マネーゲームに溺れることなく, 地道に努力して成果 を上げることが大切であることを若者に教えてくれるという，想定外の効果があった。ま た，話は変わるが，残念なことに隣国の韓国や我が国でも，科学関係での学術論文（デー 夕）捏造問題が話題となっている，軽々には判断できない部分もあるが，研究開発に携わ る一員として, 厳肃に受け止めたい。

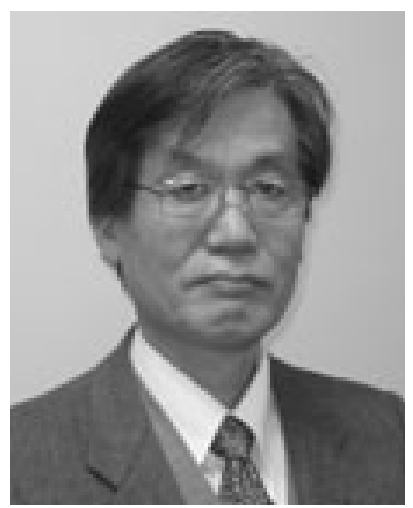

Shoichiro IKEDA 平成 17,18 年度東海支部長 名古屋工業大学大学院 工学研究科教授 